

\title{
ALIH WAHANA NOVEL HUJAN BULAN JUNI KARYA SAPARDI DJOKO DAMONO KE FILM HBJ KARYA RENI NURCAHYO HESTU SAPUTRA KAJIAN EKRANISASI
}

\author{
${ }^{1}$ Nopi Ardiansyah, ${ }^{2}$ Yayah Chanafiah, dan ${ }^{3} \mathrm{Amril}$ Canrhas \\ Universitas Bengkulu
}

Korespondensi: ardiansyanopi@gmail.com

\begin{abstract}
Abstrak
Tujuan penelitian ini adalah untuk mengetahui dan mendeskripsikan bentuk-bentuk perubahan alih wahana novel Hujan Bulan Juni ke film HBJ. Penelitian ini menggunakan metode deskriptif dengan pendekatan kualitatif. Teknik pengumpulan data menggunakan teknik membaca, menonton, menyimak dan mencatat. Teknik analisis data yang digunakan dalam penelitian ini yaitu, membaca dan memahami novel Hujan Bulan Juni, menonton film HBJ, mengidentifikasi bentuk-bentuk perubahan alih wahana novel Hujan Bulan Juni ke film HBJ, mengelompokkan bentuk-bentuk perubahan tersebut ke dalam tiga kategori yakni, pengurangan, penambahan dan perubahan bervariasi., mendeskripsikan data terkait bentuk-bentuk perubahan alih wahana novel Hujan Bulan Juni ke film HBJ, membuat kesipulan. Hasil penelitian ini menunjukkan bahwa dalam alih wahana novel Hujan Bulan Juni ke film HBJ terjadi sembilan bentuk perubahan yang terbagi ke dalam tiga kategori yakni, pengurangan, penambahan dan perubahan bervariasi. Perubahan-perubahan tersebut terjadi pada tiga unsur pembentuk karya sastra yakni, alur, tokoh dan latar. Perubahan-perubahan tersebut sangat dominan terjadi pada kategori pengurangan sehingga film HBJ hampir membentuk cerita baru. Hal tersebut dikarenakan banyak bagian-bagian dari novel Hujan Bulan Juni yang tidak dimunculkan atau dihilangkan, namun pengurangan-pengurangan yang terjadi tersebut terjadi pada bagian-bagian yang tidak terlalu penting sehingga film HBJ tetap mempertahankan inti cerita yang disampaikan di dalam novel Hujan Bulan Juni.
\end{abstract}

Kata kunci : alih wahana, novel, film, Hujan Bulan Juni

\footnotetext{
Abstract

The purpose of this study was to determine and describe the forms of change of the transformation of the novel Hujan Bulan Juni into the HBJ film. This study uses a descriptive method with a qualitative approach. The data collection technique uses reading, watching, listening, and taking notes. The data analysis techniques used in this research were reading and understanding the Hujan Bulan Juni novel, watching the HBJ film, identifying the forms of change in the transformation of the Hujan Bulan Juni novel into the HBJ film, grouping the forms of change into three categories namely, reduction, additions, and changes vary. Describing the data related to the changes in the transformation of the novel Hujan Bulan Juni vehicle to the HBJ film makes a statement. The results of this study indicate that in the transfer of the novel Hujan Bulan Juni vehicle to the HBJ film, there were nine forms of change which were divided into three categories, namely, reduction, addition, and varied changes. These changes occur in the three elements that make up literary works, namely, plot, character, and setting. These changes are very dominant in the reduction category so that the HBJ film almost forms a new story, this is because many parts of the novel
} 
Hujan Bulan Juni are not shown or removed, but the reductions that occur in parts that are not important so that the HBJ film still maintains the core story that is conveyed in the novel Hujan Bulan Juni.

Keywords: overrides, novels, films, Hujan Bulan Juni

\section{PENDAHULUAN}

Alih wahana merupakan bentuk perkembangan sastra Indonesia yang berbentuk pengalihan dari suatu karya menjadi bentuk karya yang lain. Damono (2005: 09) mengartikan alih wahana ialah proses pengalihan dari suatu jenis 'kendaraan' ke jenis 'kendaraan' lain. Sebagai 'kendaraan', suatu karya seni merupakan alat yang bisa mengalihkan sesuatu dari satu tempat ke tempat lain. Wahana diartikan juga sebagai medium yang dipergunakan untuk mengungkapkan, mencapai, atau memamerkan gagasan atau perasaan. Damono, (2018: 12) beberapa istilah yang biasa dikenal dalam kaitanya dengan kegiatan atau hasil alih wahana adalah, ekranisasi, musikalisasi, dramatisasi, dan novelisasi.

Dalam penelitian ini penulis membahas alih wahana novel Hujan Bulan Juni ke film HBJ, namun sebelumnya karya sastra ini sudah beberapa kali mengalami alih wahana yakni dari puisi menjadi lagu, menjadi komik, lalu menjadi novel, kemudian beralih wahana menjadi film yang dikenal juga dengan ekranisasi (Damono, 2018). Eneste, (1991: 60) mengatakan bahwa yang dimaksud dengan ekranisasi adalah pelayarputihan atau pemindahan atau pengangkatan sebuah novel ke dalam film (ecran dalam bahasa Prancis berarti layar). Ekranisasi sendiri merupakan bentuk alih wahana sedangkan alih wahana sendiri adalah kajian yang lebih luas daripada ekranisasi.

Kebanyakan karya-karya yang mengalami ekranisasi tersebut merupakan karyakarya fenomenal seperti, karya Dewi Lestari berjudul Super Nova diangkat menjadi film oleh Rizal Mantovani, karya Andrea Hirata berjudul Laskar Pelangi diangkat menjadi film oleh Affandi Abdul Rahman, dan karya-karya fenomenal lainnya seperti, Ketika Cinta Bertasbih, Tenggelamnya Kapal Van Der Wijk, Ayat-ayat Cinta, 5cm, Habibie Ainun, dan tentunya Hujan Bulan Juni. Dengan beralihnya sebuah novel menjadi film diharapkan dapat membawa kesuksesan atau kepopuleran yang sama terhadap film tersebut.

Novel Hujan Bulan Juni sendiri awalnya adalah sebuah karya yang sangat populer, hal ini penulis lihat berdasarkan beberapa review dari para pembaca yang penulis peroleh yaitu, menurut artikel yang terbit di gramedia.com dan goodreads.com, novel Hujan Bulan Juni karya Sapardi Djoko Damono memproleh rating 3,61/5 bintang lalu melalui gramedia.com juga dalam sebuah artikelnya yang berjudul "ini dia 10 buku sastra terpopuler terbitan gramedia pustaka utama" novel Hujan Bulan Juni menempati posisi teratas dari 10 novel yang disebutkan. Hal ini lah yang membuat novel Hujan Bulan Juni layak untuk diangkat ke layar lebar. Kemudian lahirlah film HBJ yang juga menuai kepopuleran yang sama, seperti pada beberapa review yang sudah penulis rangkum berikut, menurut website imdb.com film HBJ memperoleh rating 7,7/10 bintang, angka 7,7 tersebut ternyata mengalahkan rating film Ada Apa Dengan Cinta dengan rating 7,4/10, film 5cm dengan rating 7,2/10, film Susah Sinyal dengan rating 7,3/10, dan juga membawahi rating film Teman Tapi Menikah dengan rating 7,2/10 dan juga berdasarkan web site ngepop.com dalam sebuah review yang ditulis oleh Hanifa Eka Ramadhayani ia memberikan rating 7/10 bintang, lalu menurut web site bioskoptoday.com juga berdasarkan sebuah review oleh Prima Anita ia memberikan rating 6,5/10 bintang. Kepopuleran yang didapatkan oleh film HBJ tersebut tidak lepas dari proses pengubahan karya itu sendiri yakni dari bentuk 
linguistik menjadi bentuk audio visual yang dalam hal ini disebut ekranisasi. Selain itu film HBJ ini juga melibatkan seorang penulis novelnya yakni Sapardi Djoko Damono sebagai salah satu aktor, hal ini bisa saja menjadi salah satu faktor kepopuleran film HBJ sekaligus yang membedakan karya ini dengan karya-karya lain yang juga mengalami ekranisasi namun tidak menuai kepopuleran yang sama antara novel dan filmnya akibat perbedaan yang muncul dari kedua karya tersebut.

Pada dasarnya perbedaan-perbedaan tersebut hadir karena kedua karya tersebut memiliki media yang berbeda. Novel adalah karya yang medianya berbentuk teks sedangkan film medianya berbentuk audio visual. Sehingga setelah sebuah novel beralih wahana menjadi film akan terjadi perubahan-perubahan seperti, perubahan alur, pengurangan tokoh, penambahan tokoh, penambahan latar, variasi dialog, dsb.

Berdasarkan penjelasan di atas penulis melakukan penelitian alih wahana novel Hujan Bulan Juni ke film HBJ dengan kajian ekranisasi untuk melihat bentuk-bentuk perubahan yang terjadi dan juga sebagai alasan dibalik kepopuleran film HBJ yang tentunya berbeda dengan karya-karya lain yang juga mengalami alih wahana. Sehingga dengan demikian rumusan masalah dalam penelitian ini ialah bagaimana bentuk-bentuk perubahan alih wahana novel Hujan Bulan Juni ke film HBJ dan tentu saja penelitian ini bertujuan untuk mendeskripsikan bentuk-bentuk perubahan tersebut. Pada akhirnya penelitian ini mampu memberikan manfaat sebagai bahan literasi dalam pengembangan karya sastra dimasa depan terkhususnya pada bidang kajian alih wahana.

\section{METODE}

Penelitian ini menggunakan pendekatan kualitatif dengan metode deskriptif yaitu data yang dikumpulkan mengambil bentuk kata-kata atau gambar daripada angka-angka (Emzir, 2011: 03). Teknik pengumpulan data yang penulis gunakan dalam penelitian ini ialah teknik membaca, menonton, menyimak dan mencatat dimana wujud data dalam penelitian ini berupa kutipan-kutipan dan gambar ynag penulis ambil dari sumber data yang berupa buku novel Hujan Bulan Juni karya Sapardi Djoko Damono dan film HBJ karya Reni Nurcahyo Hestu Saputra. Kemudian instrumen dalam penelitian ini adalah penulis sendiri dimana penulis sebagai alat pengumpul data utama yang berkedudukan sebagai perencana, pelaksana pengumpulan data, penganalisis, penafsir data dan pada akhirnya menjadi pelapor hasil penelitian.

Untuk menganalisis data-data yang telah penulis peroleh, penulis menggunakan langkah-langkah berikut ini:

1. Membaca dan memahami novel Hujan Bulan Juni karya Sapardi Djoko Damono.

2. Menonton film HBJ karya Reni Nurcahyo Hestu Saputra.

3. Mengidentifikasi bentuk-bentuk perubahan alih wahana novel Hujan Bulan Juni ke film HBJ.

4. Mengelompokkan bentuk-bentuk perubahan tersebut ke dalam tiga kategori sesuai dengan teori ekranisasi yaitu, pengurangan, penambahan, dan perubahan bervariasi.

5. Mendeskripsikan data mengenai bentuk-bentuk perubahan alih wahana dari novel Hujan Bulan Juni ke film HBJ.

6. Menyimpulkan hasil temuan. 


\section{HASIL DAN PEMBAHASAN}

Berdasarkan hasil penelitian yang dilakukan penulis peroleh sembilan bentuk perubahan yang tergolong menjadi tiga kategori perubahan yaitu :

1. Pengurangan

2. Penambahan

3. Perubahan Bervariasi

Berikut penjelasan tiga kategori data tersebut.

\section{Pengurangan}

Pengurangan merupakan dihilangkannya bagian di dalam novel Hujan Bulan Juni baik itu alur, tokoh ataupun latar cerita sehingga bagian tersebut tidak diperlihatkan di dalam film HBJ. Dalam penelitian ini data berupa pengurangan diperoleh sebanyak 61 data yang kemudian data tersebut terbagi menjadi tiga bentuk yakni, pengurangan bagian alur, pengurangan bagian tokoh dan pengurangan bagian latar. Pada bagian pengurangan alur diperoleh data sebanyak 33 data, kemudian pengurangan tokoh diperoleh data sebanyak 11 data dan pengurangan latar diperoleh 17 data. Data berupa pengurangan ini penulis peroleh dari bagian-bagian adegan di dalam novel Hujan Bulan Juni yang tidak dimunculkan ke dalam film HBJ.

Berdasarkan data yang penulis dapatkan, perubahan berupa pengurangan merupakan perubahan yang paling dominan terjadi dalam alih wahana novel Hujan Bulan Juni ke film HBJ dan perubahan berupa pengurangan yang terjadi pada novel Hujan Bulan Juni menunjukkan bahwa tidak semua bagian yang ada di dalam novel Hujan Bulan Juni mampu dimunculkan ke dalam film HBJ. Pengurangan-pengurangan tersebut terjadi karena beberapa alasan yaitu, pertama, dikarenakan media yang digunakan film untuk menyampaikan cerita adalah audio visual yang mana sangat terbatas akan durasi, kedua, dikarenakan bagian-bagian yang muncul di dalam novel Hujan Bulan Juni tersebut tidak termasuk ke dalam bagian yang penting di dalam cerita sehingga tidak akan menimbulkan keanehan jika bagian tersebut di hilangkan dan terakhir karena biaya produksi sebuah film yang terbilang cukup besar maka beberapa bagian di dalam novel Hujan Bulan Juni dipilih-pilih bagian mana yang harus dimunculkan ataupun yang harus dihilangkan.

\section{Penambahan}

Penambahan merupakan pemunculan suatu bagian di dalam film HBJ yang berupa alur cerita, tokoh atapun latar cerita, yang mana sebelumnya bagian tersebut tidak berasal dari novel Hujan Bulan Juni. Data berupa penambahan penulis dapati sebanyak 41 data. Data penambahan tersebut juga terbagi ke dalam tiga kategori yakni, penambahan bagian alur, penambahan bagian tokoh dan penambahan bagian latar. Pada penambahan alur didapati 18 data, penambahan tokoh didapati 5 data dan penambahan latar didapati 18 data.

Data berupa penambahan ini penulis peroleh dari bagian-bagian di dalam film HBJ yang muncul yang mana bagian tersebut tidak berasal dari novel HBJ yang mana hal tersebut mengartikan bahwa dalam penambahan-penambahan tersebut murni karena adanya kebutuhan dari segi filmis dan juga berdasarkan jumlah penambahan yang dilakukan yang terbilang tidak banyak juga turut menguatkan bahwa penambahan yang terjadi benar-benar penambahan yang dilakukan karena adanya kebutuhan dari segi filmis terlepas dari unsur apa yang mengalami penambahan. 


\section{Perubahan Bervariasi}

Perubahan bervariasi adalah mempertahankan suatu bagian di dalam novel Hujan Bulan Juni untuk dimunculkan kembali ke dalam film HBJ baik itu alur, tokoh ataupun latar dengan memberikan beberapa variasi pada bagian tersebut yang bisa berupa penambahan, pengurangan ataupun kedua-duanya. Data berupa perubahan bervariasi penulis peroleh dari novel Hujan Bulan Juni yang kemudian penulis cocokkan dengan keadaan di dalam film HBJ dan penulis dapati sebanyak 15 data. Ke 15 data tersebut terbagi lagi kedalam tiga kategori yaitu perubahan bervariasi bagian alur sebanyak 10 data, perubahan bervariasi bagian tokoh sebanyak 2 data dan perubahan bervariasi bagian latar sebanyak 3 data.

Data perubahan bervariasi ini penulis peroleh dengan cara melihat kedua bagian yang sama diantara bagian yang ada di dalam novel Hujan Bulan Juni dengan bagian yang sama yang dimunculkan ke dalam film HBJ namun dengan beberapa variasi. Variasi yang dimaksudkan berupa penambahn, pengurangan ataupun keduanya. Perubahan bervariasi ini terjadi pada bagian yang dianggap cukup memberikan dampak positif ke dalam film HBJ. Contohnya seperti terjadinya perubahan bervariasi pada tokoh ayah Sarwono yang mana variasi yang dihadirkan adalah menghadirkan sosok Sapardi Djoko Damono dan berperan sebagai ayah Sarwono. Perubahan tersebut tentu saja memancing minat penikmat karya Sapardi Djoko Damono terlebih penikmat karya Hujan Bulan Juni itu sendiri untuk turut menyaksikan film tersebut. Selain itu dengan hadirnya sosok Sapardi Djoko Damono tersebut juga membuat film HBJ terlihat berbeda dari karya-karya lainnya yang juga merupakan hasil dari alih wahana.

Secara keseluruhan perubahan-perubahan dalam alih wahana novel Hujan Bulan Juni ke film HBJ tidak selalu tepat, artinya ada beberapa perubahan-perubahan yang sebenarnya tidak seharusnya dilakukan misalnya adanya penghilangan suatu adegan yang seharusnya adegan tersebut dapat membuat film menjadi lebih berwarna dengan konflik yang lebih menarik jika adegan tersebut dimunculkan namun adegan tersebut dihilangkan. Kemudian pada kasus lainnya adalah penambahan, sama halnya dengan pengurangan dimana penambahan yang terjadi juga tidak tepat, penambahan yang dilakukan adalah penambahan yang tidak seharusnya dilakukan sehingga penambahan yang dilakukan tidak menambah nilai serta kualitas cerita.

\section{PENUTUP}

\section{Kesimpulan}

Berdasarkan hasil penelitian dan pembahasan dapat disimpulkan bahwa perubahanperubahan yang terjadi dalam alih wahana novel Hujan Bulan Juni menjadi film HBJ hampir membentuk sebuah karya baru. Hal tersebut dikarenakan banyaknya perubahanperubahan yang terjadi dalam bentuk pengurangan, yang artinya hanya sebagian kecil saja bagian novel Hujan Bulan Juni yang diperlihatkan di dalam film HBJ tanpa mengalami perubahan. Hanya saja film HBJ tidak menghilangkan inti cerita awal yakni inti cerita yang ada di dalam novel Hujan Bulan Juni, hal tersebut dikarenakan berbagai perubahan yang dilakukan terjadi pada bagian-bagian yang tidak terlalu mempengaruhi cerita, sehingga meskipun banyak mengalami perubahan-perubahan, inti cerita yang diinginkan tetap seperti yang digambarkan di dalam novel Hujan Bulan Juni. 


\section{Saran}

Berdasarkan penelitian yang telah penulis lakukan terhadap novel Hujan Bulan Juni yang beralih wahana menjadi film HBJ, penulis menyadari bahwa penelitian ini masih dapat dikembangkan lagi menjadi lebih luas mengingat bahwa novel Hujan Bulan Juni ini tidak serta-merta sebuah karya yang lahir sendiri. novel Hujan Bulan Juni ini sendiri merupakan produk alih wahana dari puisi Hujan Bulan Juni dan tidak hanya sebatas puisi, novel dan film saja, namun Hujan Bulan Juni juga telah dikembangkan dalam bentuk karya lain seperti lagu dan komik dan berdasarkan pandangan penulis, penelitian ini mampu dikembangkan lebih luas lagi dan penelitian ini dapat menjadi bahan referensi untuk pengembangan karya sastra di masa depan terkhusus bidang kajian alih wahana.

\section{DAFTAR PUSTAKA}

Damono, S. D. (2005). Pegangan Penelitian Sastra Bandingan. Jakarta: Pusat Bahasa Departemen Pendidikan Nasional.

Damono, S. D. (2018). Alih Wahana. Jakarta: PT Gramedia Pustaka Utama.

Damono, S. D. (2018). Hujan Bulan Juni. Jakarta: PT Gramedia Pustaka Utama.

Eneste, P. (1991). Novel dan Film. Flores: Nusa Indah.

Emzir, d. (2011). Metodologi Penelitian Kualitatif Analisis Data. Jakarta: PT Raja Grafindo Persada. 